\title{
Childfree Perspektif Hak Reproduksi Perempuan dalam Islam
}

\author{
Uswatul Khasanah \\ Mahasiswa Pascasarjana IAIN Ponorogo \\ uswatulkhasanah28@gmail.com
}

\section{Muhammad Rosyid Ridho \\ Mahasiswa Pascasarjana UIN Sunan Gunung Djati Bandung muhammadrosyid726@gmail.com}

\begin{abstract}
The decision to be childfree raises a negative stigma from society. Childfree can be defined as a view of husband and wife who decide not to have children. Childfree is not a new term, many married couples in major countries choose this decision. The decision in choosing childfree in domestic life cannot be separated from the role of husband and wife. This is because it concerns their reproductive rights. Reproductive rights between husband and wife have been discussed in Islam. Departing from this phenomenon, the authors are interested in conducting research with the aim of analyzing the child-free phenomenon from the perspective of women's reproductive rights in Islam. This research was conducted with the research method used in this study is library research with a normative juridical approach. Data collection techniques with documentation and analysis using descriptive methods and content (content analysis). Deciding to be childfree must be accompanied by mature and conscious thought. The decision to choose child-free is one of the applications of reproductive rights, namely the right to refuse pregnancy. To realize this right, the concept of partner relations between husband and wife must be applied in a household. The decision in choosing to be childfree must be accompanied by a discussion between husband and wife. In the discussion, both parties must be open, especially the women, regarding the reasons for the child-free decision. In giving the reasons, it must also be accompanied by strong basic reasons so that it does not harm both parties.
\end{abstract}

Keywords: Childfree, Women's Rights, Husband and Wife Relations. 
Abstrak: Keputusan untuk childfree memunculkan stigma negatif dari masyarakat. Childfree dapat didefinisikan sebagai sebuah pandangan suami istri yang memutuskan untuk tidak mempunyai anak. Childfree bukanlah istilah baru, banyak pasangan suami istri di negara-negara besar yang memilih keputusan tersebut. Keputusan dalam memilih childfree dalam kehidupan rumah tangga tidak lepas dari peran suami istri. Hal ini karena menyangkut hak-hak reproduksi mereka. Hak reproduksi antara suami istri ini telah dibahas dalam Islam. Berangkat dari fenomena tersebut, maka penulis tertarik untuk melakukan penelitian dengan tujuan untuk menganalisis fenomena childfree dengan perspektif hak-hak reproduksi perempuan dalam Islam. penelitian ini dilakukan dengan metode penelitian yang digunakan dalam penelitian ini adalah kepustakaan (library research) dengan pendekatan yuridis normatif. Teknik pengumpulan data dengan dokumentasi serta dilakukan analisis dengan metode deskriptif dan isi (content analysis). Memutuskan untuk childfree haruslah dibarengi dengan pemikiran yang matang dan penuh kesadaran. Keputusan memilih childfree merupakan salah satu pengaplikasian dari hak reproduksi yaitu hak menolak kehamilan. Untuk mewujudkan hak tersebut, konsep relasi mitra antara suami dan istri haruslah diterapkan dalam sebuah rumah tangga. Keputusan dalam memilih untuk childfree harus dibarengi dengan diskusi antara suami istri. Dalam diskusi tersebut kedua pihak harus terbuka terutama pihak perempuan tentang alasan keputusan childfree itu dilakukan. Dalam memberikan alasan tersebut juga harus disertai alasan dasar yang kuat sehingga tidak merugikan kedua pihak.

Kata Kunci: Childfree, Hak Perempuan, Relasi Suami Istri.

\section{PENDAHULUAN}

Dewasa ini, semakin majunya peradaban umat manusia, semakin banyak permasalahan yang kompleks dan terkadang menimbulkan sebuah perdebatan di kalangan umat manusia. Tak terkecuali dengan istilah childfree. Childfree akhir-akhir ini menjadi perbincangan hangat di berbagai kalangan masyarakat. Childfree merupakan sebuah pandangan di mana pasangan suami istri memilih untuk tidak memiliki anak. Ada banyak alasan yang 
melatarbelakangi kenapa seseorang bersama pasangannya memutuskan untuk melakukan childfree diantaranya yaitu karena kekhawatiran tumbuh kembang anak, masalah personal, masalah finansial dan bahkan karena isu permasalahan lingkungan. ${ }^{1}$ Istilah childfree ini mulai mencuat di kalangan masyarakat Indonesia, karena pernyataan seorang influencer yaitu Gita Savitri yang memutuskan untuk tidak memiliki anak, Gita Savitri bersama suaminya Paul Andre Partohap bersepakat untuk tidak memiliki anak. ${ }^{2}$ Mereka beranggapan bahwa memiliki anak bukanlah sebuah kewajiban, akan tetapi merupakan sebuah pilihan hidup. Keputusan yang diambil kedua pasangan tersebut tentu merupakan keputusan personal kedua belah pihak. Akan tetapi, keputusan untuk tidak mempunyai anak, tentu memunculkan stigma negatif di masyarakat. Hal tersebut dikarenakan budaya di masyarakat khususnya di Indonesia, bahwa seseorang yang sudah memasuki usia dewasa dituntut untuk segera menikah, dan tujuan dari menikah tersebut adalah memiliki anak. Tak heran jika ada banyak pasangan yang mengalami tekanan jika belum dikaruniai anak ketika sudah menikah cukup lama.

Istilah childfree mungkin masih terdengar asing di masyarakat Indonesia, akan tetapi di negara-negara besar seperti Amerika Serikat, istilah tersebut sudah umum dikenal luas oleh masyarakat. Berdasarkan laporan dari National Survey of Family Growth dikutip dari www.gooddoctor.com tak kurang 15\% wanita dan 24\% laki-laki memutuskan untuk tidak memiliki anak. ${ }^{3}$ Sementara itu, di Kanada

1 Humas Uns, "Childfree dari Kacamata Psikolog UNS," Universitas Sebelas Maret (blog), 1 Juli 2021, https://uns.ac.id/id/uns-update/childfree-dari-kacamatapsikolog-uns.html.

2 Parapuan.co, “Selain Gita Savitri, Ini 6 Public Figure yang Memutuskan untuk Childfree - Parapuan," Parapuan.co, 5 September 2021, https:// www.parapuan.co/read/532874233/selain-gita-savitri-ini-6-public-figure-yangmemutuskan-untuk-childfree.

3 "Mengenal Konsep Child-free: Menikah Tapi Tak Ingin Punya Anak | Good Doctor | Tips Kesehatan, Chat Dokter, Beli Obat Online," Good Doctor | Tips Kesehatan, Chat Dokter, Beli Obat Online, 25 Agustus 2021, https://www.gooddoctor.co.id/hidup-sehat/info-sehat/mengenal-konsep-child-freemenikah-tapi-tak-ingin-punya-anak/. 
berdasarkan survei dari General Social Survey (GSS) pada tahun 2001 mengungkap bahwa $7 \%$ orang di Kanada berusia 20-34 tahu, mewakili 434.000 orang menyatakan berniat tidak memiliki anak. ${ }^{4}$ Sementara itu, 4\% dari orang-orang di Kanada menyatakan bahwa pernikahan merupakan hal yang penting, juga tidak memiliki ketertarikan atau keinginan untuk memiliki anak. ${ }^{5}$ Beberapa alasan yang melatar belakangi childfree di Kanada ini diantaranya yaitu, kondisi medis yang tidak memungkinkan, situasi tidak kondusif dalam membesarkan anak, karir yang memuaskan serta alasanalasan lingkungan atas keputusan mereka untuk tidak memiliki anak. $^{6}$

Bicara mengenai childfree tidak lepas dari peran suami istri. Peran suami istri dalam keputusan untuk childfree menjadi penting adanya. Hal ini karena menyangkut hak-hak reproduksi mereka. Hak-hak reproduksi dalam hubungan suami istri ini telah diatur di dalam Islam. Menurut Husein Muhammad, hak reproduksi ini dibagi menjadi empat, yaitu hak menikmati hubungan seksual, hak menolak hubungan seksual, hak menolak kehamilan, serta hak menggugurkan kandungan (aborsi). ${ }^{7}$ Hak-hak reproduksi tersebut tidak hanya dimiliki oleh salah satu pasangan saja, tetapi dimiliki oleh keduanya. ${ }^{8}$ Hal tersebut telah diatur dalam Islam, di mana dalam hubungan rumah tangga, laki-laki dan perempuan memiliki peran yang setara. Meskipun laki-laki dan perempuan memiliki kodrat yang berbeda, tetapi mereka memiliki peran yang sama. Keduanya (laki-laki dan perempuan) diciptakan dari sebuah esensi

4 Statistics Canada Government of Canada, "Child Free by Choice ARCHIVED," 28 Oktober 2021，2， https://www150.statcan.gc.ca/n1/pub/11-008x/2003001/article/6528-eng.pdf.

${ }^{5}$ Government of Canada, 4.

${ }^{6}$ Government of Canada, 2.

${ }^{7} \mathrm{KH}$. Husein Muhammad Muhammad, Figh Perempuan Refleksi Kiai atas Tafsir Wacana Agama dan Gender (Yogyakarta: IRCiSoD, 2019), 270.

8 Evra Willya, "HAK-HAK REPRODUKSI DALAM PANDANGAN ISLAM," Marwah: Jurnal Perempuan, Agama dan Jender 11, no. 1 (2 Juni 2012): 14, https://doi.org/10.24014/marwah.v11i1.497. 
yang sama, karena nya keduanya juga didorong untuk berperan secara aktif dalam kehidupan rumah tangga.

Adanya relasi antara suami dan istri menjadi hal yang sangat penting dalam membuat keputusan childfree ini. Hal ini karena Islam telah memberikan hak-hak reproduksi yang sama antara suami dan khususnya bagi istri. Berangkat dari fenomena tersebut, maka penulis tertarik untuk melakukan penelitian dengan judul childfree perspektif hak reproduksi perempuan dalam Islam. Adapun tujuan dari penelitian ini adalah untuk menganalisis fenomena childfree dengan perspektif hak-hak reproduksi perempuan dalam Islam.

Penelitian dengan tema childfree telah banyak dilakukan, diantaranya oleh Wanda Roxanne Ratu Pricillia dalam bukunya yang berjudul Menjadi Perempuan Lajang Bukan Masalah, ada satu bab yang membahas mengenai childfree. Dalam bab yang diberi judul Memiliki Keluarga Normal sebagai Perempuan Childfree disimpulkan bahwa memiliki ataupun tidak memiliki anak dalam sebuah keluarga memiliki konsekuensi dan hal ini merupakan sebuah pilihan hidup. Apapun keputusan seorang perempuan dalam hal memilih memiliki ataupun tidak memiliki anak haruslah didukung dan dihormati. ${ }^{9}$ Kedua, penelitian oleh Miwa Patnani, Bagus Takwin dan Winarni Wilman Mansour yang melakukan studi empiris mengenai dampak ketidakadaan anak dalam sebuah pernikahan. Penelitian yang menggunakan pendekatan fenomenologi ini menghasilkan sebuah temuan bahwa adanya anak dalam sebuah pernikahan memberikan dampak positif bagi pasangan suami istri. ${ }^{10}$ Studi empiris selanjutnya juga dilakukan oleh Imam Syaifudin. Penelitian ini berfokus pada implementasi dari hak menolak kehamilan menurut pandangan KH. Husein Muhammad. Kesimpulan dari penelitian tersebut dikatakan bahwa pemahaman perempuan di Kelurahan Klojen mengenai kesehatan reproduksi

9 Wanda Roxanne Ratu Pricillia, Menjadi Perempuan Lajang Bukan Masalah (Yogyakarta: Odise Publishing, 2021), 62.

10 Miwa Patnani, Bagus Takwin, dan Winarini Wilman Mansoer, "Bahagia tanpa anak? Arti penting anak bagi involuntary childless," Jurnal Ilmiah Psikologi Terapan 9, no. 1 (15 Januari 2021): 117, https:/ / doi.org/10.22219/jipt.v9i1.14260. 
masih cukup rendah. Adapun mengenai hak menolak kehamilan, mayoritas informan setuju akan hal itu. Alasan para informan ini diantaranya adalah ekonomi, usia dan kesehatan. ${ }^{11}$ Dari ketiga kajian terdahulu tersebut didapatkan persamaan dalam hal topik penelitian yaitu childfree atau menolak kehamilan. Adapun perbedaannya terletak pada perspektif yang peneliti gunakan yaitu dengan hak reproduksi perempuan dalam Islam. Kedua, pada aspek metodologi penelitian, ketiga kajian terdahulu di atas menggunakan studi empiris, sedangkan penelitian yang peneliti lakukan di sini menggunakan studi pustaka.

Seperti yang telah disinggung sebelumnya, metode penelitian yang digunakan dalam penelitian ini adalah kepustakaan (library research) dengan pendekatan yuridis normatif. Sumber data yang peneliti gunakan adalah buku dari Masdar F. Mas'udi yang berjudul Islam dan Hak-Hak Reproduksi Perempuan. Kedua, buku dari Wanda Roxanne Ratu Pricillia yang berjudul Menjadi Perempuan Lajang Bukan Masalah. Selanjutnya, beberapa artikel yang membahas mengenai childfree. Data-data tersebut peneliti kumpulkan dengan teknik dokumentasi serta dilakukan analisis dengan metode deskriptif dan isi (content analysis).

\section{PEMBAHASAN}

\section{Hak Reproduksi Perempuan dalam Islam}

Islam sangat menghargai posisi perempuan, hal tersebut tercermin dalam Alquran. Hal ini terbukti dari sekian banyak nama surah dalam Alquran, terdapat Surah an-Nisa' (perempuan). Ada pula surah yang menyebut nama perempuan yaitu Surah Maryam. Selanjutnya ada Surah yang membahas sebagian masalah perempuan, contohnya surah al Thalaq. Salah satu masalah yang dibahas dalam Alquran dan hadis adalah masalah yang berkaitan dengan hak-hak reproduksi. Menurut Husein Muhammad, hak reproduksi ini dibagi menjadi empat, yaitu hak adalah hak

11 Imam Syaifudin, "Pandangan Perempuan Tentang Hak Menolak Kehamilan Perspektif KH. Husein Muhammad," SAKINA 4, no. 3 (2020): 1. 
menikmati hubungan seksual, hak menolak hubungan seksual, hak menolak kehamilan, serta hak menggugurkan kandungan (aborsi). ${ }^{12}$ Selain empat hak reproduksi tersebut, ada pendapat lain yang menambahi hak reproduksi ini. Pendapat lain yang di maksud adalah pendapat Masdar F. Mas'udi. Menurut Masdar F. Mas'udi, bagian dari hak reproduksi adalah hak memilih pasangan, hak merawat anak, hak cuti reproduksi, dan hak menceraikan pasangan. ${ }^{13}$

Pertama, hak menikmati hubungan seksual. Konsekuensi dari sebuah pernikahan adalah dilakukannya hubungan seksual antara suami dan istri. Kenikmatan hubungan seksual ini haruslah dirasakan oleh kedua belah pihak. Untuk mewujudkan hak tersebut, hubungan seksual tersebut harus dilakukan tanpa paksaan oleh salah satu pihak. ${ }^{14}$ Hak menikmati hubungan seksual ini telah diatur dalam surah al-Baqarah ayat 187

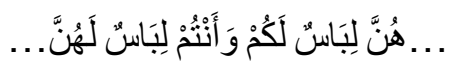

“...mereka adalah selimut bagi kamu, dan kamu adalah selimut bagi mereka..."

Ayat di atas menjelaskan bahwa posisi antara suami dan istri adalah setara. Pada hakikatnya hubungan suami istri adalah hubungan kerja sama, di mana hubungan suami istri tersebut haruslah saling menyempurnakan, saling menyadari dan tidak boleh merasa kedudukannya lebih tinggi di antara keduanya. Dengan demikian harus mendapatkan hak dalam menikmati hubungan seksual. ${ }^{15}$ Kedua, hak menolak hubungan seksual. Hak tersebut diberikan pada suami istri guna mencegah terjadinya kekerasan

270.

12 Muhammad, Figh Perempuan Refleksi Kiai atas Tafsir Wacana Agama dan Gender,

${ }^{13}$ Masdar F. Mas'udi, Islam \& Hak-Hak Reproduksi Perempuan Dialog Fiqih Pemberdayaan (Bandung: Mizan, 1997), 144.

14 Waliko Waliko, "Islam, Hak dan Kesehatan Reproduksi," Komunika: Jurnal Dakwah dan Komunikasi 7, no. 2 (1 Januari 1970): 64, https://doi.org/10.24090/komunika.v7i2.384.

15 Abd. Rozaq dan Ulil Fauziyah, "Idealism Relasi Suami Istri pada Era New Normal dalam Perspektif Hukum Alquran," dalam Konferensi Nasional 2020 Hukum dan Birokrasi (Konferensi Nasional 2020 Hukum dan Birokrasi, Malang: Universitas Islam Malang, 2021), 60. 
seksual. Salah satu bentuk kekerasan seksual adalah pemaksaan seksual atau degradasi seksual misalnya mengejar aktivitas seksual ketika salah satu pasangan tidak sepenuhnya sadar atau takut untuk mengatakan tidak. ${ }^{16}$

Ketiga, dalam Alquran dipaparkan bahwa perempuan yang sedang hamil berada pada kondisi yang berat dan melemahkan. Kondisi ini semakin berat ketika perempuan memasuki tahap melahirkan, bahkan berisiko pada kematian. Mengingat hal tersebut, akan menjadi masuk akal dan harus menjadi perhatian bersama jika perempuan mempunyai hak atau pilihan menolak untuk hamil. Mayoritas ulama fikih berpendapat bahwa anak bukan hanya hak suami atau hak istri saja, namun anak merupakan hak bersama antara suami dan istri. Dengan demikian jika istri tidak menghendaki kehamilan, maka suami harus mempertimbangkannya. ${ }^{17}$

Mengenai hal tersebut, ada perbedaan pendapat dikalangan para ulama. Pertama, pendapat Al-Ghozali dari kalangan madzab syafi'i berpendapat bahwa yang berhak memutuskan dalam memiliki anak adalah suami. Dengan demikian, jika suami berkehendak memiliki anak, maka istri tidak memiliki hak untuk menolaknya. Kedua, pendapat mayoritas ulama hanafiyah mengatakan bahwa yang berhak menentukan memiliki anak atau tidak adalah suami dan istri. Ketiga, pendapat di kalangan ulama Hanafiyah dan sebagian ulama Syafi'iyah berpendapat bahwa yang menentukan memiliki anak atau tidak bukan hanya hak suami dan istri, tetapi juga umat/masyarakat, dengan tetap menekankan keputusan tersebut pada suami dan istri. Keempat, pendapat yang dianut oleh para ahli hadis, di mana yang berhak menentukan

16 Bhennita Sukmawati, "Hubungan tingkat kepuasan pernikahan istri dan coping strategy dengan kekerasan dalam rumah tangga," Psychological Journal: Science and Practice 2, no. 3 (2014): 208. 270.

17 Muhammad, Figh Perempuan Refleksi Kiai atas Tafsir Wacana Agama dan Gender, 
memiliki anak atau tidak terletak pada kepentingan umat/masyarakat atau bisa disebut dengan kepentingan negara. ${ }^{18}$

Hak reproduksi selanjutnya, hak melakukan aborsi. Aborsi dapat didefinisikan sebagai tindakan mengakhiri kehamilan. Beberapa ulama membolehkan tindakan ini pada kondisi sebelum bayi ditiupkan ruhnya. Namun, ada juga sebagian ulama yang mengharamkannya karena dianggap membunuh bayi, kecuali dalam kondisi darurat dan hajat. ${ }^{19}$ Pandangan ulama akan kebolehan tindakan aborsi ini menunjukkan bahwa ada pemberian hak-hak reproduksi. Kelima, hak memilih pasangan. Keberadaan perempuan diakui oleh Islam, hal ini terlihat dari pemberian kebebasan bagi perempuan untuk memilih pasangannya yang cocok baginya. Selain itu, Islam juga melarang wali menikahkan secara paksa anak gadis dan saudara perempuannya dengan orang yang tidak disukasinya. Menurut Al-Syarawi, ayah atau wali dapat menentukan jodoh bagi anak gadis atau saudara perempuannya, namun dengan syarat harus meminta izin terlebih dahulu pada perempuan tersebut, karena perempuan itulah yang akan menjalankan perkawinan. Hak memilih pasangan ini tidak serta merta tanpa sebuah tujuan. Tujuan utama dari hak ini adalah ketentraman dan kedamaian bagi para pihak dalam melangsungkan kehidupan rumah tangganya. ${ }^{20}$

Selanjutnya, cuti reproduksi. Dalam Islam cuti reproduksi merupakan salah satu hak reproduksi bagi perempuan. Pemberian hak ini dengan maksud untuk melindungi kesehatan perempuan baik fisik maupun mental. Hal ini karena ketika fungsi reproduksi perempuan sedang berjalan, pasti akan mempengaruhi fisik-biologis sekaligus pada mental-psikologis. Terakhir, hak menceraikan pasangan. Anggapan yang memiliki hak menceraikan pasangan dalam Islam hanya hak suami pada dasarnya tidak sepenuhnya

18 Masdar F. Mas'udi, Islam \& Hak-Hak Reproduksi Perempuan Dialog Fiqih Pemberdayaan (Bandung: Mizan, 1997), 123-25.

${ }_{19}$ Nilda Susilawati, "Aborsi Dalam Tinjauan Hukum Islam," JURNAL ILMIAH MIZANI: Wacana Hukum, Ekonomi, dan Keagamaan 2, no. 2 (2020): 113.

${ }^{20}$ Istibsyaroh, Hak-Hak Perempuan (Relasi Jender menurut Tafsir Al-Sya'rawi) (Jakarta: TERAJU, 2004), 98-101. 
benar. Islam telah memberikan hak pada perempuan untuk mengambil keputusan pada dirinya sendiri, termasuk di dalamnya menceraikan suami. Hak tersebut dalam Islam disebut dengan istilah khulu'. Secara bahasa khulu' berarti melepas. Maksud dari melepas di sini adalah apabila istri merasa tidak lagi cocok dengan suaminya, istri dapat meminta pengadilan untuk menceraikannya dengan alasan-alasan yang dibenarkan oleh hukum. ${ }^{21}$

\section{Relasi Suami Istri dalam Hukum Islam}

Dalam Islam, laki-laki dan perempuan memiliki peran yang setara baik dalam hubungan rumah tangga atau pun dalam lingkungan kerja. Meskipun laki-laki dan perempuan memiliki kodrat yang berbeda, tetapi mereka memiliki peran yang sama baik dalam ranah rumah tangga dan ranah domestik. Keduanya (laki-laki dan perempuan) diciptakan dari sebuah esensi yang sama, karena nya keduanya juga didorong untuk berperan secara aktif dalam sektor publik maupun domestik. Diantara kesetaraan hak laki-laki dan perempuan adalah pertama, kesetaraan hak seksual. Kedua, kesetaraan membuat keputusan dalam rumah tangga. Ketiga, kesetaraan untuk mendapatkan warisan. Keempat, kesetaraan sebagai saksi.

Secara umum, pernikahan antara laki-laki dan perempuan demi mewujudkan rumah tangga yang bahagia didasarkan oleh beberapa prinsip diantaranya, pertama, dalam rangka membangun ketaatan kepada Allah, disini seks bermakna ibadah. Selanjutnya, pernikahan adalah bentuk untuk mewujudkan ketenteraman (sakinah), rasa cinta (mawaddah) dan kasih saying (warahmah), dan seks di sini menjadi suatu kebahagiaan manusiawi untuk kedua pasangan. Terakhir, sebagai sarana menciptakan kehidupan yang bersih dari perilaku memperturutkan nafsu syahwat belaka, sehingga seks di sini dapat diartikan sebagai sebuah makna untuk

162.

${ }^{21}$ Mas'udi, Islam E Hak-Hak Reproduksi Perempuan Dialog Fiqih Pemberdayaan, 
menjalin atau membangun kualitas komunikasi antar suami dan istri. 22

Selain itu, menurut Faqihuddin Abdul Qadhir, dalam mewujudkan kebaikan tujuan dunia dan akhirat, terdapat lima pilar penyangga kehidupan rumah tangga diantaranya yaitu: ${ }^{23}$

1 Mitsaqan ghalizhan (berkomitmen terhadap ikatan janji yang kokoh)

2 Zawa (prinsip berkepasangan dan berkesalingan)

3 Taradhim (saling memberi kenyamanan)

4 Muasharah bil ma'ruf (saling memperlakukan dengan baik)

5 Musyawarah (kebiasaan saling berembuk bersama pasangan) Jika lima pilar tersebut dapat dijalankan oleh pasangan suami dan istri maka tujuan keluarga akan didapatkan oleh kedua belah pihak

Berkaitan dengan relasi suami dan istri setidaknya ada dua prinsip ajaran yang penting. Pertama, persamaan hak suami dan istri (sexual equality). Hal tersebut sesuai dengan hadis yang diriwayatkan oleh Abu Dawud dari 'Aisyah r.a menuturkan bahwa Rasulullah Saw. Bersabda, "perempuan itu saudara kandung laki-laki". ${ }^{24}$ Dari hadis tersebut dapat difahami bahwa perempuan merupakan manusia yang sama seperti laki-laki yang memerlukan pengakuan, penghargaan, perlindungan dan pemenuhan hak hak hidup sebagai manusia yang bermartabat dan memiliki harga diri tanpa kekerasan, penistaan dan peminggiran. ${ }^{25}$

Kedua, Relasi yang baik atau mu'āsharah bi al-ma'rüf dapat diartikan sebagai pergaulan, persahabatan, kekeluargaan dan kekerabatan yang dibangun secara bersama sama dengan cara yang baik dan sesuai tradisi di masyarakat serta tidak menyalahi norma norma yang ada baik agama, akal sehat dan fitrah manusia. $m u^{\prime} a>$ sharah bi al-ma'ru>f dalam kehidupan perkawinan dapat

22 Milda Rahma, Marital Rape (Yogyakarta: Pustaka Pesantren, 2007), 48.

${ }^{23}$ Faqihuddin Abdul Kodir, Qira'ah Mubadalah (Yogyakarta: IRCiSoD, 2019),

342.

24 Faqihuddin Abdul Kodir, 60 Hadits Shahih Khusus Tentang Hak Hak Perempuan Dalam Islam (Yogyakarta: Diva Press, 2019), 49.

25 Kodir, 51.c 
ditandai dengan adanya sikap saling memberi dan menerima antara suami dan istri, juga sikap saling mengasihi dan menyayangi, tak saling memperlihatkan kebencian dan tidak saling mengabaikan hak serta kewajiban masing masing. Selain itu, prinsip mu'a>sharah bi al$m a$ 'ru $>f$ menuntut adanya kebersamaan dalam banyak hal termasuk dalam hal keputusan untuk memiliki keturunan atau tidak.

Selain itu, secara umum kriteria relasi yang baik antara suami dan istri dapat dijabarkan sebagai berikut:

1 Menerima kondisi pasangan apa adanya. Kesadaran untuk menimbang kelebihan dan kekurangan pasangan, kemudian menerimanya dengan tulus dan ikhlas karena Allah merupakan modal utama untuk melanggengkan rumah tangga.

2 Saling memahami serta menjalankan hak dan kewajiban. Suami dan istri dalam sebuah rumah tangga sama-sama memiliki hak dan kewajiban. Setiap hak dan tanggungjawab kelak akan diminta pertanggungjawaban nya di hadapan Allah, tak terkecuali peran sebagai suami ataupun istri.

3 Mengembangkan sikap amanah dan menegakkan kejujuran. Kepercayaan dalam membangun rumah tangga merupakan barang mahal yang tak ternilai harganya. Karena itu, pernikahan juga disebut sebagai amanah Allah yang harus dijalankan dengan penuh tanggung jawab.

4 Saling memahami perbedaan pendapat dalam memilih peran. Suami dan istri yang baik adalah jika keduanya mampu memahami tentang berbagai perbedaan masing-masing. Ketika relasi keduanya diciptakan dalam iklim kesetaraan dan keadilan gender dapat memudahkan, tidak hanya sekedar memahami tetapi telah tumbuh sénsitivitas terhadap perbedaan pendapat yang sering muncul dalam rumah tangga.

5 Saling memberdayakan untuk kualitas pasangan. Suami istri yang baik adalah selalu melihat pasangannya dari sisi kebaikan pasangannya agar tetap bersyukur. Demikian pula melihat kekurangan pasangannya secara proporsional agar ada 
kesadaran untuk saling memberdayakan dalam berbagai aspek kehidupan rumah tangga.

6 Mengatasi masalah bersama. Suami dan istri yang baik yaitu mampu mengatasi persoalan rumah tangga dengan jalan diskusi, musyawarah dan membuat alternatif solusi.

7 Menghindari terjadinya kekerasan dalam rumah tangga. Kekerasan dalam rumah tangga tidak akan pernah terjadi jika rumah tangga dibangun atas dasar kesetaraan dan keadilan. Di mana suami dan istri mampu memposikan dirinya dengan pasangannya seperti saling menasehati, mengingatkan dan berpesan untuk kebaikan. ${ }^{26}$

\section{Childfree Perspektif Hak Reproduksi Perempuan dalam Islam}

Childfree merupakan sebutan bagi orang yang memutuskan untuk tidak memiliki anak. Secara bahasa childfree diartikan sebagai bebas-anak. Beberapa orang ada yang menganggap keputusan tersebut sebagai sebuah keputusan yang egois. Meskipun demikian, ada juga yang menilai bahwa keputusan tersebut bukan sebuah keputusan yang egois, akan tetapi keputusan yang berdasarkan pemikiran yang matang dan penuh kesadaran. Memutuskan untuk memiliki anak berarti juga harus siap untuk menanggung segala tanggung jawab yang diemban sebagai orang tua. Begitu pula jika memilih untuk childfree. ${ }^{27}$

Konsep childfree dalam kajian fiqih diilustrasikan sebagai bentuk kesepakatan menolak kelahiran atau wujud anak, baik sebelum anak potensial wujud ataupun setelahnya. Dalam kajian fiqih ada beberapa padanan kasus, yaitu menolak wujudnya anak sebelum sperma berada di rahim wanita, baik dengan cara, pertama, tidak menikah sama sekali. Kedua, dengan cara menahan diri tidak bersetubuh setelah pernikahan. Ketiga, dengan cara tidak inzal atau

26 Mufidah, Psikologi Keluarga Islam Berwawasan Gender (Malang: UIN-Maliki Press, 2013), 162-70.

27 Rizki Eka Kurniawan, "Childfree dan Ulama yang Memilih Menjomblo Sampai Mati," Mubadalah.id (blog), Oktober 2021, https://mubadalah.id/childfree-danulama-memilih-menjomblo-sampai-mati/. 
tidak menumpahkan sperma di dalam rahim setelah memasukkan penis ke vagina. Keempat, dengan cara 'azl atau menumpahkan sperma di luar vagina. Keempat hal di atas secara substansial sama dengan pilihan childfree dari sisi sama-sama menolak wujudnya anak sebelum berpotensial wujud. Apabila childfree yang dimaksud adalah menolak wujudnya anak sebelum potensial wujud, yaitu sebelum sperma berada di rahim wanita, maka hukumnya boleh. ${ }^{28}$

Keputusan memilih childfree dalam sebuah kehidupan rumah tangga merupakan sebuah hak bagi pasangan suami istri. Hak yang dimaksud di sini adalah hak reproduksi. Hak reproduksi ini telah diatur dalam Islam, khususnya hak reproduksi bagi perempuan. Menurut Husein Muhammad, hak reproduksi ini dibagi menjadi empat, yaitu hak menikmati hubungan seksual, hak menolak hubungan seksual, hak menolak kehamilan, serta hak menggugurkan kandungan (aborsi). ${ }^{29}$ Keputusan memilih childfree merupakan salah satu bentuk aplikasi dari hak menolak kehamilan. Hak menolak kehamilan ini diberikan oleh agama Islam kepada perempuan. Hal ini merupakan bukti bahwa agama Islam sangat menghargai posisi perempuan. Perempuan diberi hak menolak kehamilan tersebut dikarenakan perempuanlah yang menanggung tanggung jawab serta segala risiko dalam mengandung, melahirkan, dan menyusui. Allah pun telah mendeskripsikan ketiga tanggung jawab yang hanya bisa ditanggung oleh perempuan dalam AlQur'an surah Al-Ahqaf ayat 15.

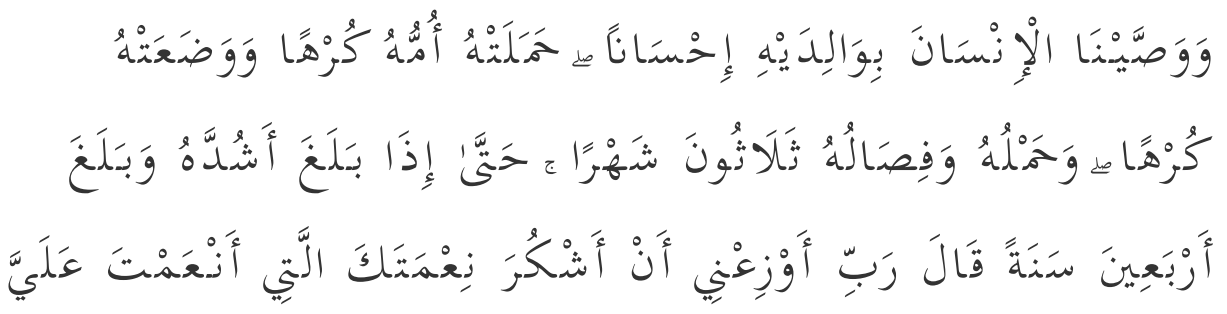

28 "Hukum Asal Childfree dalam Kajian Fiqih Islam | NU Online," diakses 3 November 2021, https:/ / nu.or.id/nikah-keluarga/hukum-asal-childfree-dalam-kajianfiqih-islam-CuWgp. 270 .

${ }^{29}$ Muhammad, Figh Perempuan Refleksi Kiai atas Tafsir Wacana Agama dan Gender, 


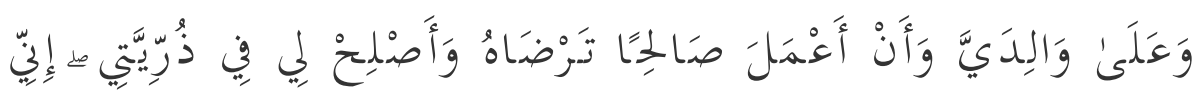

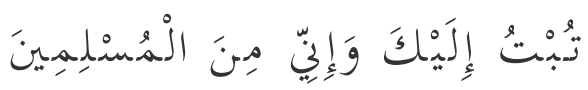

Artinya: “Kami perintahkan kepada manusia supaya berbuat baik kepada dua orang ibu bapaknya, ibunya mengandungnya dengan susah payah, dan melahirkannya dengan susah payah (pula). Mengandungnya sampai menyapihnya adalah tiga puluh bulan, sehingga apabila dia telah dewasa dan umurnya sampai empat puluh tahun ia berdoa: "Ya Tuhanku, tunjukilah aku untuk mensyukuri nikmat Engkau yang telah Engkau berikan kepadaku dan kepada ibu bapakku dan supaya aku dapat berbuat amal yang saleh yang Engkau ridhai; berilah kebaikan kepadaku dengan (memberi kebaikan) kepada anak cucuku. Sesungguhnya aku bertaubat kepada Engkau dan sesungguhnya aku termasuk orangorang yang berserah diri"'"

Lebih lanjut, perempuan yang sedang hamil lambat laun kondisinya bertambah lemah. Hal ini juga telah didiskripsikan dalam Al-Qur'an surah Luqman ayat 14.

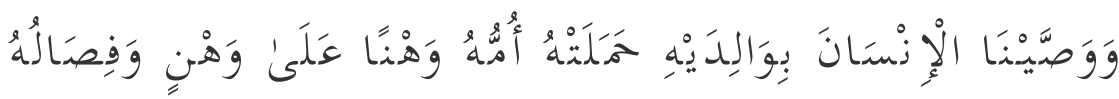

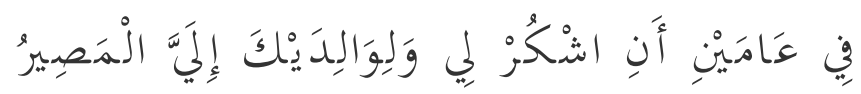

Artinya: "Dan Kami perintahkan kepada manusia (berbuat baik) kepada dua orang ibu-bapaknya; ibunya telah mengandungnya dalam keadaan lemah yang bertambah-tambah, dan menyapihnya dalam dua tahun. Bersyukurlah kepada-Ku dan kepada dua orang ibu bapakmu, hanya kepada-Kulah kembalimu."

Hak reproduksi, yang dalam hal ini adalah hak menolak kehamilan dapat diwujudkan dengan prinsip bermitra yang sejajar antara suami dan istri. Relasi mitra antara suami dan istri sangat diperlukan agar tidak terdapat ketimpangan dalam sebuah keluarga, sehingga perempuan akan mendapatkan hak-haknya termasuk hak reproduksi nya. Ketika hak reproduksi tersebut terpenuhi, maka 
jaminan kesehatan dan keselamatan akan terjaga. Karena pada dasarnya hak reproduksi perempuan tersebut sebagai cara perempuan untuk memutuskan serta melaksanakan keputusankeputusan terhadap hak reproduksi nya secara aman dan efektif, salah satunya adalah hak menolak kehamilan. Dengan demikian tujuan rumah tangga yang penuh dengan ketentraman, kasih sayang dan penuh cinta tidak mustahil akan terwujud. ${ }^{30}$

Dalam hal bermitra tersebut setidaknya ada dua hal yang harus diperhatikan yaitu hak suami dan istri (sexual equality) dan relasi yang baik antara keduanya (mu'āsharah bi al-ma'rüf). Dengan melihat dua konsep di atas, maka ketika memutuskan childfree dalam sebuah rumah tangga tentu harus melalui keputusan yang sangat matang. Hal tersebut dikarenakan akan ada konsekuensi yang tidak mainmain antara kedua pasangan dan bahkan ke keluarga kedua belah pihak. Diskusi yang masif antara suami dan istri merupakan salah satu cara membangun komunikasi yang efektif antara suami dan istri dalam mengambil keputusan childfree. Dalam diskusi tersebut kedua pihak harus terbuka terutama pihak perempuan tentang alasan keputusan childfree itu dilakukan. Dalam memberikan alasan tersebut juga harus disertai alasan dasar yang kuat sehingga tidak merugikan kedua pihak. Jika bermitra sejajar ini diterapkan dalam pengambilan keputusan childfree maka akan menimbulkan beberapa sifat yaitu diantaranya:

1 Sikap saling pengertian antar pasangan

2 Saling menerima dalam kekurangan dan kesenangan

3 Saling menghormati dan menghargai

$4 \quad$ Saling mempercayai

5 Saling mencintai dengan lemah lemah lembut

Dalam sebuah pernikahan, misi utamanya adalah sebuah kemaslahatan sehingga memiliki anak merupakan tujuan lain dari pernikahan dan bukan merupakan tujuan utama. Hal tersebut sesuai

${ }^{30}$ Rusdi Ma'ruf, “Pemahaman Dan Praktik Relasi Suami Isteri Keluarga Muslim Di Perum Reninggo Asri Kelurahan Gumilir Kabupaten Cilacap," Al-Ahwal: Jurnal Hukum Keluarga Islam 8, no. 1 (14 Juni 2015): 38, https://doi.org/10.14421/ahwal.2015.08103. 
dengan apa yang sudah dijelaskan di atas bahwa ada lima pilar dalam pernikahan diantaranya, pertama, mitsaqan ghalidhan yaitu perjanjian yang kokoh. Kedua belah pihak berjanji, bersepakat, dan berkomitmen untuk hidup bersama dan berumah tangga untuk mewujudkan sakinah mawaddah wa rahmah. Ikatan yang kokoh ini harus dijaga, dipelihara, dirawat serta dilestarikan bersama oleh kedua belah pihak serta dipertanggungjawabkan dihadapan Allah Swt. Dengan ikatan yang kuat dan kokoh suami dan istri akan jauh lebih mudah dalam menopang serta menyangga seluruh sendi-sendi dalam kehidupan rumah tangga. Hal tersebut terdapat dalam alQur'an surat an-Nisaa' Ayat 21.

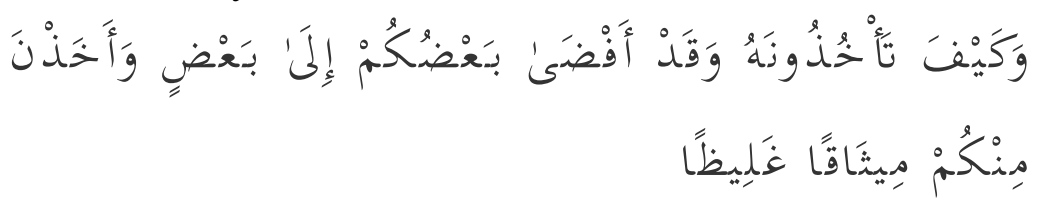

Artinya: Bagaimana kamu akan mengambilnya kembali, padahal sebagian kamu telah bergaul (bercampur) dengan yang lain sebagai suami-isteri. Dan mereka (isteri-isterimu) telah mengambil dari kamu perjanjian yang kuat. (QS. An-Nisaa': 21)

Kedua, Zawaj atau dapat diartikan sebagai pergaulanan dalam sebuah perkawinan, maksudnya adalah dalam sebuah perkawinan antara suami dan istri merupakan individu yang saling melengkapi, saling menopang satu sama lain, dan saling bekerjasama dalam menciptakan iklim keluarga yang harmonis. Dalam al-Quran Surat al-Baqarah Ayat 187 dijelaskan bahwa:

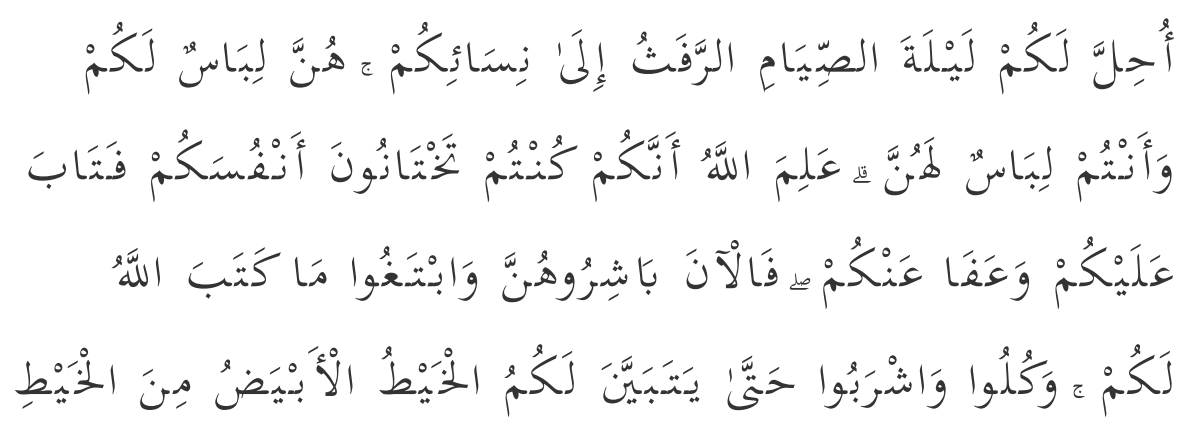




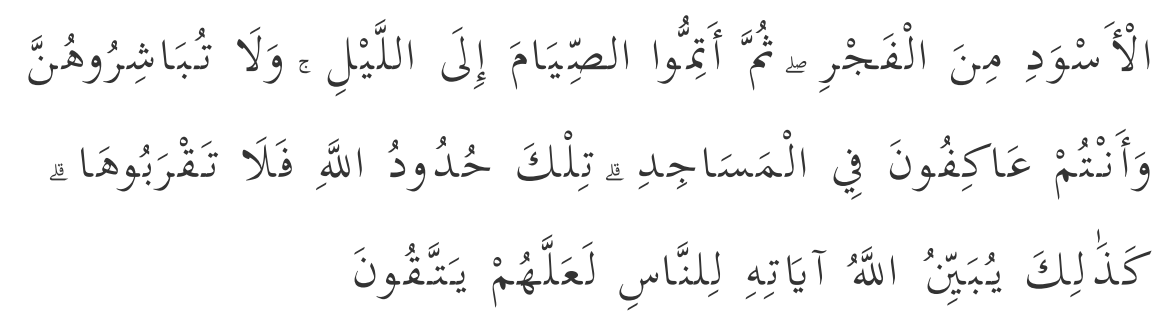

Artinya: "Dihalalkan bagi kamu pada malam hari bulan puasa bercampur dengan isteri-isteri kamu; mereka adalah pakaian bagimu, dan kamupun adalah pakaian bagi mereka. Allah mengetahui bahwasanya kamu tidak dapat menahan nafsumu, karena itu Allah mengampuni kamu dan memberi maaf kepadamu. Maka sekarang campurilah mereka dan ikutilah apa yang telah ditetapkan Allah untukmu, dan makan minumlah hingga terang bagimu benang putih dari benang hitam, yaitu fajar. Kemudian sempurnakanlah puasa itu sampai (datang) malam, (tetapi) janganlah kamu campuri mereka itu, sedang kamu beri'tikaf dalam mesjid. Itulah larangan Allah, maka janganlah kamu mendekatinya. Demikianlah Allah menerangkan ayat-ayat-Nya kepada manusia, supaya mereka bertakwa." (QS. Al-Baqarah: 187)

Ayat di atas dalam perspektif mubadalah, dapat dimaknai bahwa istri adalah pakaian suami dan suami adalah pakaian istri. Selain itu, ayat di atas juga membahas terkait dengan syariat I'tikaf di masjid yang disunnahkan bagi laki-laki dan perempuan, serta mereka satu sama lain dilarang melakukan hubungan intim ketika sedang I'tikaf. Begitupula hak atas kenikmatan seksual dari pasangan, yang ditegaskan di pangkal ayat, perempuan berhak dari suaminya, sebagaimana laki-laki dari istrinya. Hal ini menegaskan bahwa hak menikmati hubungan seksual adalah hak suami dan istri.

Ketiga, muasharah bil ma'ruf yaitu sifat memperlakukan satu sama lain dengan baik atau dapat dikatakan sebagai sifat pengormatan hak-hak dalam keluarga atau juga dapat dikatakan sebagai relasi yang baik antar keduanya. Sikap tersebut merupakan etika dasar dalam relasi suami istri. Memperlakukan satu sama lain dengan baik merupakan salah satu pilar guna menjaga dan 
menghidupkan segala kebaikan yang menjadi tujuan bersama sehingga bisa terus dirasakan dan dinikmati oleh kedua belah pihak. Pilar ketiga ini menegaskan mengenai perspektif, prinsip, dan nilai kesalingan antara suami dan istri. Bahwa kebaikan harus dihadirkan dan sekaligus dirasakan oleh kedua belah pihak. Dalam Surat anNisaa' Ayat 19 dijelaskan bahwa:

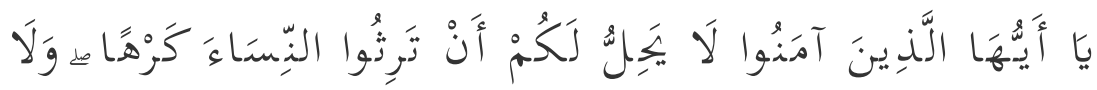

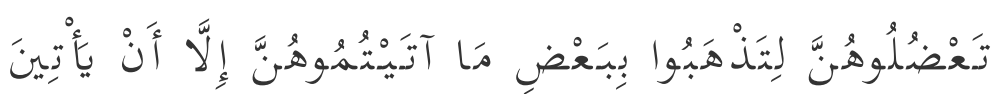

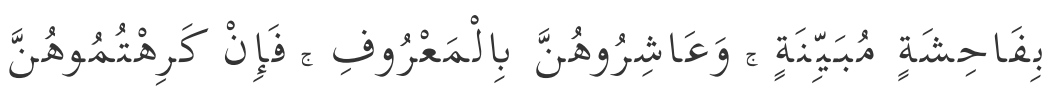

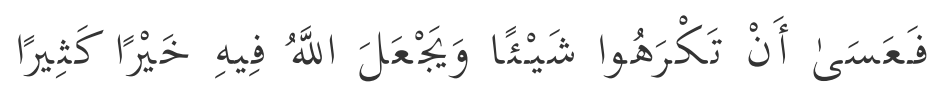

Artinya: "Hai orang-orang yang beriman, tidak halal bagi kamu mempusakai wanita dengan jalan paksa dan janganlah kamu menyusahkan mereka karena hendak mengambil kembali sebagian dari apa yang telah kamu berikan kepadanya, terkecuali bila mereka melakukan pekerjaan keji yang nyata. Dan bergaullah dengan mereka secara patut. Kemudian bila kamu tidak menyukai mereka, (maka bersabarlah) karena mungkin kamu tidak menyukai sesuatu, padahal Allah menjadikan padanya kebaikan yang banyak." (QS. anNisaa': 19)

Dalam perspektif mubadalah, baik istri ataupun suami dilarang melakukan pemaksaan terhadap satu sama lain, menghalangi, dan merampas harta. Jika ditarik ke arah keputusan childfree, maka pilihan tersebut berdasarkan tujuan bersama serta tanpa ada paksaan satu sama lain. keputusan childfree juga harus dilandasi sebuah kebaikan yang dihadirkan dan dirasakan oleh kedua belah pihak.

Keempat, sikap dan perilaku untuk selalu bermusyawarah dan saling berdiskusi dalam memutus hal-hal yang berkaitan dengan kehidupan rumah tangga. Suami maupun istri tidak boleh menjadi yang otoriter dan memaksakan kehendak. Segala hal terkait dengan kehidupan rumah tangga, tidak boleh langsung diputuskan sendiri 
tanpa melibatkan dan meminta pendapat dari pasangan. Pilar musyawarah ini dijelaskan dalam surah Ali 'Imran ayat 159 dan surah al-Baqarah ayat 233.

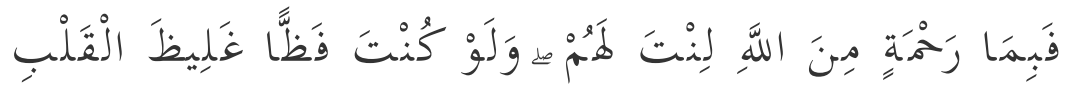

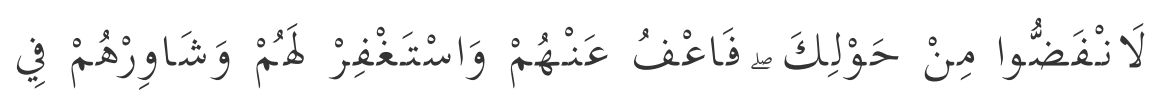

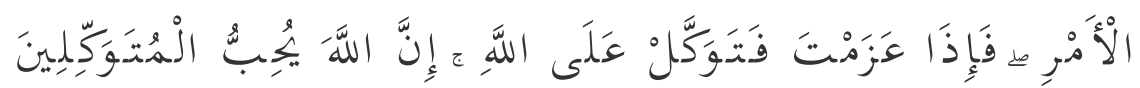

Artinya: "Maka disebabkan rahmat dari Allah-lah kamu berlaku lemah lembut terhadap mereka. Sekiranya kamu bersikap keras lagi berhati kasar, tentulah mereka menjauhkan diri dari sekelilingmu. Karena itu maafkanlah mereka, mohonkanlah ampun bagi mereka, dan bermusyawaratlah dengan mereka dalam urusan itu. Kemudian apabila kamu telah membulatkan tekad, maka bertawakkallah kepada Allah. Sesungguhnya Allah menyukai orang-orang yang bertawakkal kepada-Nya.” (QS. Ali ‘Imran: 159)

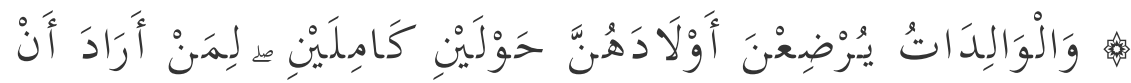

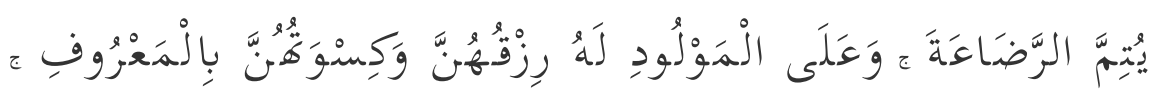

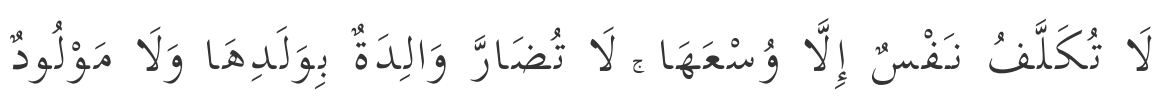

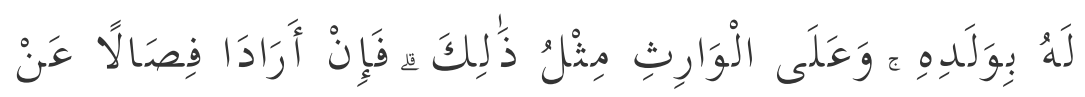

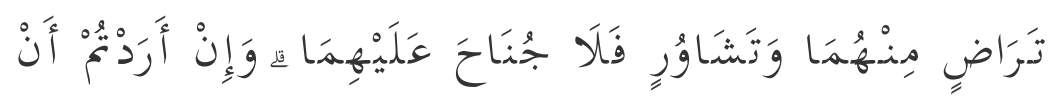

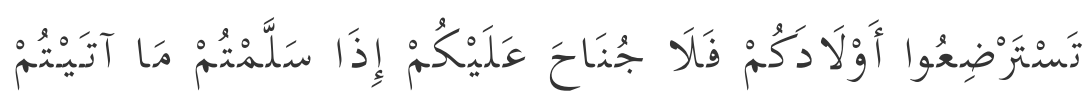

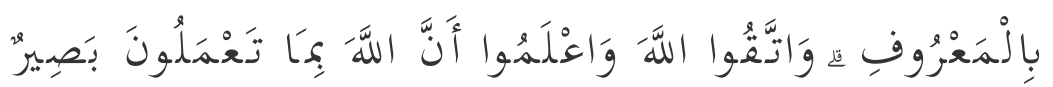

Artinya: "Para ibu hendaklah menyusukan anak-anaknya selama dua tahun penuh, yaitu bagi yang ingin menyempurnakan 
penyusuan. Dan kewajiban ayah memberi makan dan pakaian kepada para ibu dengan cara ma'ruf. Seseorang tidak dibebani melainkan menurut kadar kesanggupannya. Janganlah seorang ibu menderita kesengsaraan karena anaknya dan seorang ayah karena anaknya, dan warispun berkewajiban demikian. Apabila keduanya ingin menyapih (sebelum dua tahun) dengan kerelaan keduanya dan permusyawaratan, maka tidak ada dosa atas keduanya. Dan jika kamu ingin anakmu disusukan oleh orang lain, maka tidak ada dosa bagimu apabila kamu memberikan pembayaran menurut yang patut. Bertakwalah kamu kepada Allah dan ketahuilah bahwa Allah Maha Melihat apa yang kamu kerjakan." (QS. al-Baqarah: 233)

Kedua ayat di atas menunjukkan bahwa pentingnya bermusyawarah, tak terkecuali dalam sebuah rumah tangga. Dengan bermusyawarah tercermin sikap pengakuan dan penghargaan terhadap harga diri dan kemampuan pasangan. Selain itu, akan didapatkan pendapat dari berbagai perspektif, sehingga dalam mengambil keputusan didasari pada keadaan yang penuh kesadaran dengan berbagai manfaat dan akibat yang akan ditimbulkan dari keputusan tersebut. Salah satu hal yang juga harus di musyawarahkan bersama adalah dalam memutuskan untuk memilih childfree dalam kehidupan rumah tangga. Pilihan childfree tidak hanya terletak pada tangan istri, tetapi merupakan keputusan bersama dengan jalan musyawarah. Keputusan hasil musyawarah ini dengan berbagai pertimbangan dari segi manfaat dan akibat yang akan ditimbulkan dari keputusan childfree tersebut.

Kelima, taradhin yaitu dapat diartikan sebagai sikap pasangan dalam menjaga kerelaan dalam setiap tindakan serta memberikan kenyamanan dalam keluarga sehingga terhindar dari hal-hal yang tidak diinginkan. Yang dimaksud dengan kerelaan di sini adalah sebuah penerimaan dan kenyamanan, di mana suami maupun istri merasa rela ketika di dalam hatinya tidak ada sedikitpun ganjalan atau penolakan. Pilar kerelaan harus menjadi penyangga dalam segala aspek kehidupan rumah tangga, sehingga kehidupan rumah tangga menjadi kokoh, melahirkan rasa cinta kasih dan kebahagian. 
Pilar kelima ini didasarkan pada surat al-Baqarah Ayat 233, yang menjelaskan bahwa dalam hal penyapihan saja membutuhkan kerelaan suami istri. Pilar kelima ini juga penting untuk diaplikasikan dalam membuat keputusan childfree dalam kehidupan rumah tangga. Rasa rela di antara suami maupun istri menjadi dasar keputusan childfree. Sehingga, tujuan dari pilar kelima ini dapat terwujud.

Dari penjelasan di atas, didapatkan argument bahwa memiliki anak atau tidak merupakan pilihan bebas bagi perempuan, yang mana setiap pilihan tersebut memiliki konsekuensi sendiri-sendiri. Kebebasan inilah sebenarnya yang diperjuangkan oleh pemilih childfree ini. Akan tetapi, kebebasan ini harus didiskusikan dengan pasangan agar konsep bermitra dalam keluarga dapat dijalankan dengan baik serta tidak ada pihak yang merasa dirugikan di kemudian hari. Lebih lanjut, sebenarnya childfree ini adalah pilihan pribadi yang tidak perlu untuk diumbar-umbar dan tidak perlu memprovokasi kepada yang lain untuk mengikuti pilihan yang dipilih. Oleh karena itu, bagi perempuan generasi muda hendaklah memilih sesuai dengan pilihan mereka namun pilihan tersebut juga harus didasari alasan yang bijak dan dapat diterima.

\section{KESIMPULAN}

Memutuskan untuk childfree haruslah dibarengi dengan pemikiran yang matang dan penuh kesadaran. Keputusan memilih childfree merupakan salah satu pengaplikasian dari hak reproduksi yaitu hak menolak kehamilan. Untuk mewujudkan hak tersebut, konsep relasi mitra antara suami dan istri haruslah diterapkan dalam sebuah rumah tangga. Keputusan dalam memilih untuk childfree harus dibarengi dengan diskusi antara suami istri. Dalam diskusi tersebut kedua pihak harus terbuka terutama pihak perempuan tentang alasan keputusan childfree itu dilakukan. Dalam memberikan alasan tersebut juga harus disertai alasan dasar yang kuat sehingga tidak merugikan kedua pihak. Lebih lanjut, sebenarnya childfree ini adalah pilihan pribadi yang tidak perlu 
untuk diumbar-umbar dan tidak perlu memprovokasi kepada yang lain untuk mengikuti pilihan yang dipilih. Oleh karena itu, bagi perempuan generasi muda hendaklah memilih sesuai dengan pilihan mereka namun pilihan tersebut juga harus didasari alasan yang bijak dan dapat diterima.

\section{DAFTAR PUSTAKA}

Government of Canada, Statistics Canada. "Child Free by Choice ARCHIVED," 28 Oktober 2021.

https://www150.statcan.gc.ca/n1/pub/11-008x/2003001/article/6528-eng.pdf.

Kodir, Faqihuddin Abdul. 60 Hadits Shahih Khusus Tentang Hak Hak Perempuan Dalam Islam. Yogyakarta: Diva Press, 2019.

Kurniawan, Rizki Eka. “Childfree dan Ulama yang Memilih Menjomblo Sampai Mati." Mubadalah.id (blog), Oktober 2021. https://mubadalah.id/childfree-dan-ulama-memilihmenjomblo-sampai-mati/.

Ma'ruf, Rusdi. "Pemahaman dan Praktik Relasi Suami Isteri

Keluarga Muslim di Perum Reninggo Asri Kelurahan Gumilir Kabupaten Cilacap." Al-Ahwal: Jurnal Hukum Keluarga Islam 8, no. 1 (14 Juni 2015): 37.

https://doi.org/10.14421/ahwal.2015.08103.

Mas'udi, Masdar F. Islam \& Hak-Hak Reproduksi Perempuan Dialog Fiqih Pemberdayaan. Bandung: Mizan, 1997.

Good Doctor | Tips Kesehatan, Chat Dokter, Beli Obat Online.

"Mengenal Konsep Child-free: Menikah Tapi Tak Ingin Punya Anak | Good Doctor | Tips Kesehatan, Chat Dokter, Beli Obat Online," 25 Agustus 2021.

https://www.gooddoctor.co.id/hidup-sehat/infosehat/mengenal-konsep-child-free-menikah-tapi-tak-inginpunya-anak/.

Mufidah. Psikologi Keluarga Islam Berwawasan Gender. Malang: UINMaliki Press, 2013. 
Muhammad, KH. Husein Muhammad. Figh Perempuan Refleksi Kiai atas Tafsir Wacana Agama dan Gender. Yogyakarta: IRCiSoD, 2019.

Parapuan.co. “Selain Gita Savitri, Ini 6 Public Figure yang Memutuskan untuk Childfree - Parapuan." Parapuan.co, 5 September 2021.

https://www.parapuan.co/read/532874233/selain-gitasavitri-ini-6-public-figure-yang-memutuskan-untuk-childfree.

Patnani, Miwa, Bagus Takwin, dan Winarini Wilman Mansoer.

"Bahagia tanpa anak? Arti penting anak bagi involuntary childless." Jurnal Ilmiah Psikologi Terapan 9, no. 1 (15 Januari 2021): 117. https://doi.org/10.22219/jipt.v9i1.14260.

Pricillia, Wanda Roxanne Ratu. Menjadi Perempuan Lajang Bukan Masalah. Yogyakarta: Odise Publishing, 2021.

Rahma, Milda. Marital Rape. Yogyakarta: Pustaka Pesantren, 2007.

Rozaq, Abd., dan Ulil Fauziyah. "Idealism Relasi Suami Istri pada Era New Normal dalam Perspektif Hukum Alquran." Dalam Konferensi Nasional 2020 Hukum dan Birokrasi. Malang:

Universitas Islam Malang, 2021.

Sukmawati, Bhennita. "Hubungan tingkat kepuasan pernikahan istri dan coping strategy dengan kekerasan dalam rumah tangga." Psychological Journal: Science and Practice 2, no. 3 (2014): 205-18. Susilawati, Nilda. "Aborsi Dalam Tinjauan Hukum Islam." JURNAL ILMIAH MIZANI: Wacana Hukum, Ekonomi, dan Keagamaan 2, no. 2 (2020).

Syaifudin, Imam. "Pandangan Perempuan Tentang Hak Menolak Kehamilan Perspektif KH. Husein Muhammad." SAKINA 4, no. 3 (2020).

Uns, Humas. "Childfree dari Kacamata Psikolog UNS." Universitas Sebelas Maret (blog), 1 Juli 2021. https:/ / uns.ac.id/id/unsupdate/childfree-dari-kacamata-psikolog-uns.html.

Waliko, Waliko. "Islam, Hak dan Kesehatan Reproduksi."

KOMUNIKA: Jurnal Dakwah dan Komunikasi 7, no. 2 (1 Januari 1970). https:/ / doi.org/10.24090/komunika.v7i2.384. 
Willya, Evra. "Hak-Hak Reproduksi dalam Pandangan Islam.” Marwah: Jurnal Perempuan, Agama dan Jender 11, no. 1 (2 Juni 2012): 1. https:// doi.org/10.24014/marwah.v11i1.497.

"Hukum Asal Childfree dalam Kajian Fiqih Islam | NU Online." Diakses 3 November 2021. https://nu.or.id/nikahkeluarga/hukum-asal-childfree-dalam-kajian-fiqih-islamCuWgp.

Istibsyaroh. Hak-Hak Perempuan (Relasi Jender menurut Tafsir AlSya'rawi). Jakarta: TERAJU, 2004.

Kodir, Faqihuddin Abdul. Qira'ah Mubadalah. Yogyakarta: IRCiSoD, 2019.

Mas'udi, Masdar F. Islam \& Hak-Hak Reproduksi Perempuan Dialog Fiqih Pemberdayaan. Bandung: Mizan, 1997. 